\title{
Study Level Of Community Participation In Environmental Management In Fish Processing Units (Case Study : Kaliori District, Rembang Regency)
}

\author{
Theresia Vika Ayuningrum ${ }^{*}$ and Hartuti Purnaweni
}

Master Program of Environmental Science, School of Postgraduate Studies, Diponegoro University, Semarang - Indonesia

\begin{abstract}
Rembang Regency is one of the biggest catching fish producing regions in Central Java. Abundant marine fisheries products encourage the development of processed fish products. There are 2,740 Fish Processing Units, but most are still dominated by small and medium scale areas. Activities in the fish processing unit have a positive impact on the economy of the community, but on the side it raises new problems such as a decrease in environmental quality. Indonesia through Law Number 32 of 2009 concerning Environmental Protection and Management includes participatory principles as one of the principles in the formulation of every policy related to the environment. This study aims to analyze the level of community participation and perception in environmental management in the fish processing unit in Kaliori District. This research is descriptive qualitative. The data used are primary and secondary data. The results obtained indicate that the community's perception of environmental management is quite good, but community participation in environmental management in the area of fish processing units in Kaliori District is still relatively low
\end{abstract}

Keywords: Rembang; Participation and Perception; Fish Processing Units.

* Corresponding author: vikaayuningrum89@gmail.com 


\section{Introduction}

Indonesia is an archipelagic state consisting of approximately 17,504 island groups, with a sea area of 6.4 million $\mathrm{km} 2$ with a coastline of 108,000 km [1]. This makes Indonesia recognized as the largest archipelago country as well as the owner of the longest productive coastline in the world [2]. Indonesia also has the highest biodiversity potential in terms of the number of fish and coral reefs of all countries on the coast of the Indian and Pacific oceans [3].

The fisheries sector is one of the supporting sectors of the national economy that has strategic value. Growth in the Gross Domestic Product (GDP) of fisheries throughout 20142017 has always been above the growth of the National GDP and Agriculture GDP. Indonesia is the largest producer of fisheries in the world besides China [4].

Fishery products are food that is easily damaged by spoilage microorganisms and enzymes, so it needs good handling to maintain its quality [5]. Here the fish processing unit plays an important role in maintaining quality and providing value added products. Fish Processing Unit is a place and facility to carry out fish handling and / or processing activities [6]. In Indonesia there are 61,246 fish processing units which include 60,429 micro and small scale fish processing units (98.8\%) and 817 units (1.2\%) large scale processing units [7].

Small and medium scale fish processing units that dominate in Indonesia are still traditional processing using simple techniques and tools. Quality and raw materials vary greatly or there are no definitive standards. The types of activities include baking, baking, smoking, salting and other processing [8]. The many small and medium scale fish processing units that are done in addition to providing increased welfare for the community, also have a negative impact on the surrounding environment [9].

Environmental problems in the area of fish processing units can be grouped into two, namely environmental problems caused by nature and those caused by human behavior [9].

Research conducted on the fish smoking unit in Semarang with a total population of 69 respondents mentioned that as many as $51.4 \%$ of producers included in the category of bad hygiene and $48.6 \%$ included in the category of good hygiene [10]. The emergence of smoke originating from the smoking process fish contain chemicals that have the potential to cause decreased lung function in the form of particulates and gas components. Even in the fumigation location the air feels hotter which is probably due to the lack of shade plants [11].

The community is the main actor in development activities. Quality and sustainable development is development that prioritizes the community. Increasing community awareness in resource management is very important for the sustainability of an area [12]. Participation and perception are interrelated concepts. In general, before a person participates in an object, his perception and attitude will be preceded by the object and then participation will emerge. The decline in the quality of the environment caused by humans and nature will have a negative impact on the survival of human life and other living things. Concrete and consistent steps are needed as well as collaboration between policy makers, the community, academics and other stakeholders to achieve sustainable socioecological conditions [13].

Rembang Regency is one of the regions that has the second highest fishery potential in Central Java. Geographically, Rembang Regency has an area of around 101,408 Ha with a coastline of $63 \mathrm{~km}$ and a sea area of $442.80 \mathrm{~km} 2$. There are 13 Fish Auction Sites and 2,740 fish processing units [14]. 
Table 1. Fish Processing Units in Rembang

\begin{tabular}{|c|c|c|}
\hline Type Of Processed & $\begin{array}{c}\text { Fish Processing } \\
\text { Unit } \\
\end{array}$ & Labor \\
\hline Teri Nasi & 21 & 410 \\
\hline Pemindangan & 535 & 5237 \\
\hline Pengeringan/ & 970 & 11029 \\
\hline Pengasinan & & \\
\hline Pedo & 42 & 239 \\
\hline Jambal & 35 & 136 \\
\hline Pengasapan & 580 & 1176 \\
\hline Terasi & 170 & 467 \\
\hline Kerupuk & 200 & 532 \\
\hline Petis & 75 & 221 \\
\hline Presto & 45 & 126 \\
\hline Tepung Ikan & 15 & 83 \\
\hline Pengalengan & - & - \\
\hline Pembekuan & 24 & 990 \\
\hline Suri Mie & 5 & 200 \\
\hline \multirow[t]{2}{*}{ Lain-lain } & 23 & 738 \\
\hline & 2740 & 21584 \\
\hline
\end{tabular}


which decreased by $-1.7 \%$ from the previous year's production. In addition, there is also damage to the environment of coastal ecosystems such as coastal abrasion, damage to coral reef sites and not optimal mangrove areas. Implementation of coastal management policies in Rembang Regency is more visible to the economic framework than compared to the environmental domain so that it has not been able to reach a balance between social, economic and environmental dimensions [15].

One of the fish processing unit areas in Rembang lies in Kaliori District. There are large and medium scale and small scale fish processing units. Like other fish processing unit areas, fish processing units in the Kaliori sub-district are inseparable from environmental management issues that affect environmental quality. This study aims to examine the participation and public perception of environmental management in the area of the fish processing unit in the Kaliori sub-district.

\section{Methodology}

This research is a case study research using descriptive qualitative method. Descriptive method in this study aims to provide an overview of community participation and perceptions in the environmental management of the fish processing unit area in Kaliori District.

This research was conducted in three villages located in Kaliori Subdistrict, namely Tunggulsari village, Puworjo village, and Tambakagung village. This research was conducted in September to December 2019 which was started from preliminary research.

The population in this study were all fish processing unit owners and fish processing workers in three villages in the Kaliori sub-district. Respondents were determined by stratifed random sampling with the consideration that the fish processing community in three villages in Kaliori District consisted of the community who owned the fish processing unit and the fish processing community. Determination of respondents is done intentionally / with the purpose sampling method.

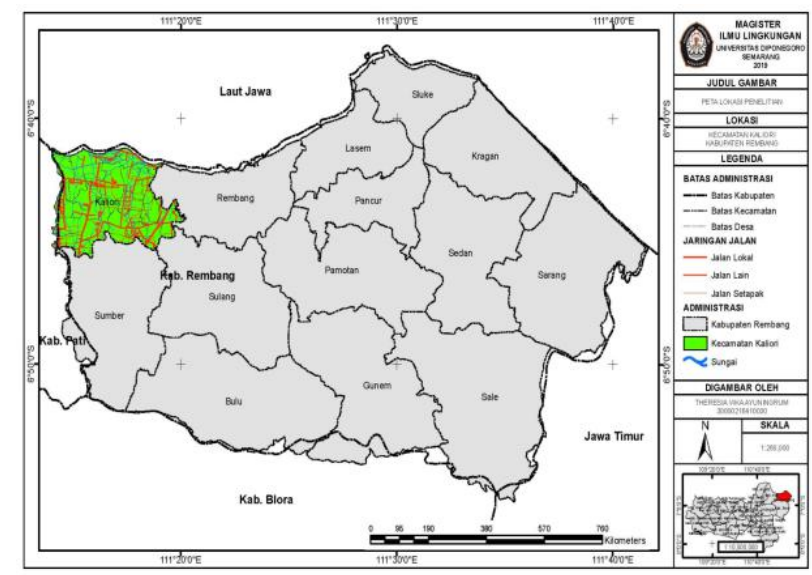

Fig. 1. Map of Research Location 
In 2013, the growth rate of Rembang Regency's marine fisheries experienced a very drastic decline.

The data collected consists of primary data and secondary data. Primary data were collected through field observations, and interviews using a structured questionnaire. Secondary data were obtained from various literatures and institutions related to this study.

\section{Results and Discussion}

Kaliori District is one of the sub-districts in the western end of Rembang regency with an area of 6,150 hectares consisting of 23 villages. Six of them are coastal villages directly adjacent to the Java Sea, namely Banyudowo, Bogoharjo, Pantiharjo, Puworejo, Tasikharjo and Tunggulsari. The total population of Kaliori District is 41,947 people consisting of 20,877 men and 21,070 women. Most of the population earning as farmers, fishermen and pond farmers. Like other coastal areas, the productive age and young age in Kaliori District are quite high [16].

\subsection{Condition of Fish Processing Unit and Potential Waste Generated}

The fish processing unit that is the location of the study is in three villages namely Tunggulsari village, Puworejo village and Tambakagung village. There are 50 fish processing units which are small-scale fish processing units and households. The types of activities in the Kaliori subdistrict fish processing unit consist of scavenging, fumigation and salting. The average daily production of 6 tons per day illustrates the number of families who depend their lives on activities in this fish processing unit. The majority of workers, both men and women are at the elementary level of education, namely $55 \%$ male workers out of all workers and 30\% female workers. That is, the level of education possessed by most workers only reaches the level of basic education but there are also those who do not attend school at all. Low education of workers, is the reason employers of fish processing units generally provide low wages.

The fish processing unit in Kaliori District is a profession that has been in the community for generations. Traditional processing practices are very difficult to change such as overriding cleanliness, sanitation and hygiene, raw materials and the application of low quality technology, as well as the conditions of the processing environment that do not meet the requirements. The aspect of human resources is largely determined by the socioeconomic environment. The social environment includes several aspects such as demographics (age, sex, migration patterns, etc.), social and cultural aspects (history, traditions, community relations, etc.), economic aspects (income and expenditure) and institutions (policies, decision making, participation) .

Based on its physical characteristics, the waste generated from the fish processing unit in the Kaliori sub-district consists of liquid, solid and gas waste. The resulting solid waste is in the form of bone debris, such as fish bones, heads, fins, skin scales, fish entrails, crab shells. From the data collected, the amount of solid waste or rubbish produced is 1.5 tons per day. 
In the washing process, turbid, fatty and smelly, liquid waste is produced which is flowed directly into the body of the river or drain. Washing water disposal systems such as household waste disposal, in the sense that there is no prior treatment. The habit results in incomplete drainage and a foul odor. This process uses water from shallow wells even though the water looks dirty and is far from healthy and hygienic, because clean water is generally difficult to obtain at processing sites.

\subsection{Community Perception and Participation in Environmental Management in the Fish Processing Unit Area.}

\subsubsection{Community Perception}

The results of the questionnaire regarding the respondents' perceptions of environmental management found that most of the level of perception of the people who carry out activities in the fish processing unit was categorized as low, namely $55 \%$, while the high level of perception was $27 \%$ and the remaining $18 \%$ had a moderate perception of environmental management. From the results of this study it can be stated that most of the processing communities in the Kaliori subdistrict fish processing unit have a low perception of the environmental conditions in their area.

\subsubsection{Community Participation}

Based on the results of the study found that out of $100 \%$ of respondents as much as $16 \%$ have a high level of participation, $33 \%$ have a moderate level of participation and $51 \%$ have a low level of participation. Thus it can be said that the level of participation of the processing community in environmental management is relatively low. Community participation is the participation of a person or group in community activities or community participation in development.

\subsection{Relationship Between Perception and Community Participation in Environmental Management in the Fish Processing Unit Area}

The higher the community's perception or understanding of environmental conditions or objects, the higher the level of community participation, and vice versa the lower the community's perception, the lower the level of community participation [17]. But in the field research what happened was the level of community perception in environmental management in the fish processing unit was relatively good or high, but the level of participation was still low [18]. These results can occur in accordance with the stated theory of social change, which includes the process of reproduction is a process of repeating, reproducing everything that was accepted as a cultural heritage of the previous ancestors. And the transformation process is the process of creating new things that are produced by science and technology, what changes is the material aspects of culture, whereas the norms are difficult to change. Most people in the fish processing unit in Kaliori District are aware of the importance of environmental management, but changing habits and participating in environmental management activities is still very difficult. 


\section{Conclucion}

The level of community participation in environmental management in the area of the fish processing unit in Kaliori District is still relatively low, but the perception of environmental management is quite high. This is related to the low level of education and knowledge of the community and the difficulty of changing habits that have been formed for a long time, besides the lack of community involvement in local environmental development programs.

\section{Reference}

[1] Badan Informasi Geospasial. Rujukan Nasional Data Kewilayahan Indonesia. BIG. Bogor (2018)

[2] Puryono, Sri. Mengelola Laut Untuk Kesejahteraan Rakyat. Gramedia Pustaka Utama. Jakarta (2016)

[3] Prasetia, A. Ekonomi Maritim Indonesia, Cetakan 1, Yogyakarta: Diandra Kreatif (2016)

[4] Food and Agriculture Organization. The state of world fisheries and aquaculture. FAO. Rome. pp 223 (2014)

[5] Hari Eko, Sri Giyatmi. Prinsip Dasar Pengolahan Hasil Perikanan.

[6] Peraturan Menteri Kelautan dan Perikanan Republik Indonesia Nomor 17/PERMENKP/2019 Tentang Persyaratan dan Tata Cara Penerbitan Sertifikat Kelayakan Pengolahan

[7] Kebijakan Kerja Sama dengan Perguruan Tinggi dalam Pemanfaatan Lulusan dan Hasil Riset. Direktorat Pengolahan dan Bina Mutu (2019)

[8] Kurniadi Sosiawan. Peran Kawasan Bahari Terpadu Rembang Terhadap Ekonomi Lokal di Desa Tasikagung Rembang (Thesis), Master Program Development And City Development Techniques. Diponegoro University. (2008)

[9] Elwina, Marcella S. Problematika Pengembangan Industri Pengasapan Ikan ( Studi Kasus Industri Pengasapan Ikan Bandarharjo, Semarang . Seminar. (2006)

[10] Puspaningdyah E Martini, Sri Yuliawati. Kontaminasi Staphylococcus aureus Pada Ikan Asap Di Tingkat Produsen Dan Penjual Di Semarang .Jurnal Universita Muhammadiyah Semarang (2008)

[11] Pranowowati, Puji. Induksi Partikel Terhirup Dalam Asap Terhadap Kapasitas Fungsi Paru Pada Pengrajin Pengasapan Ikan di Kelurahan Bandarharjo Kecamatan Semarang Utara Kota Semarang. STIKES Ngudi Waluyo. Ungaran (2007) 
[12] Ayunita, D., dan Hapsari, T.D. Analisis Persepsi dan Partisipasi Masyarakat Pesisir pada Pengelolaan KKLD Ujungnegoro Kabupaten Batang. SEPA, 9 : 117-124 (2012).

[14] Badan Pusat Statistik Kabupaten Rembang

[15] Ali, Rozikin. Kismartini.Evaluasi Dampak ebijakan Pengelolaan Wilayah Pesisir dan Laut di Kabupaten Rembang. Universitas Diponegoro. Semarang (2012)

[16] Kecamatan Kaliori Dalam Angka. Data Pusat Statistik abupaten Rembang. (2019)

[17] Endang S. Tingkat Partisipasi Masyarakat Pengolah Dalam Pengelolaan Lingkungan Sentra Pengolahan Hasil Perikanan (Kasus Di PHT Muara Angke). Thesis. Institut Pertanian Bogor. (2004)

[18] Salim A. Perubahan Sosial Sketsa Teori dan Refleksi Metodelogi Kasus Indonesia. Yogyakarta. Tiara Wacana Yogya. (2002) 